\title{
Education and a philosophical approach to teaching in elementary school around the world
}

Ji Xiuqin ${ }^{1}$

\author{
Journal for Educators, Teachers and Trainers, Vol. 12 (1) \\ https://jett.labosfor.com/
}

Date of reception: 12 October 2020

Date of revision: 10 January 2021

Date of acceptance: 09 April 2021

Ji Xiuqin (2021). Education and a philosophical approach to teaching in elementary school around the world. Journal for Educators, Teachers and Trainers, Vol. 12(1). 161 - 164.

${ }^{1}$ Professor of education, master's supervisor, is currently the dean of the school of preschool education and special education of Chifeng University, China 


\title{
Education and a philosophical approach to teaching in elementary school around the world \\ Ji Xiuqin ${ }^{1}$
}

${ }^{1}$ Professor of education, master's supervisor, is currently the dean of the school of preschool education and special education of Chifeng University, China

Email ID: 15847396999@126.com

\begin{abstract}
This article attempts to analyze modern education systems in relation to the philosophy of education. The paper presents comparative data of educational systems of different countries of the world, that have interesting and significant differences, taking into account national, religious, economic and political characteristics.
\end{abstract}

Keywords: philosophy, education, pedagogy, pedagogical methods, primary school, basic education, country.

\section{INTRODUCTION}

Philosophy of education is a branch of education that evaluates all theories and applications related to education from a holistic point of view, trying to describe the problems that hinder education, as well as the concepts, thoughts and principles that guide education and shape educational policy. The philosophy of education forms the educational beliefs of teachers and this affects their views, values and decisions, and is also a determining factor in organizing the learning environment, carrying out educational activities in interaction with students [5]. Thus, it can be said that educators around the world need to have an understanding of the educational philosophy they are adopting so that they can improve their teaching practice.

When teaching children in elementary school, each country has a unique philosophy based on the best models, methods and approaches characteristic of its own ethnic group, cultural background, pedagogical history of its state, historical and political realities of specific periods of the life of society, including the modern one.

Differences in the process of basic education of preschool and primary school education, including the philosophical foundations, differ, but the goal remains the same - the upbringing and education of the younger generation, based on respect for the culture of their country.

The world on planet Earth is multifaceted and unique. Every country, whether it is with the highest level of development of sciences, such as Russia, the United States of America, the countries of Central Europe, Scandinavia and Central Asia - China, South Korea and Japan, as well as developing countries in Africa, Afghanistan, Cuba and others with a low standard of living, formed due to the problems of historical development, territorial and military-political factors, in spite of everything they strive to improve their educational systems and methods of training the child population of their countries.

Nevertheless, despite many significant differences in educational approaches to teaching young people, similarities in education around the world undoubtedly exist.

In most developed countries, children are encouraged to continue their education in primary school until the completion of a full course of 10-12 years of school. Although the worldwide average dropout rate after primary school is only $6 \%$, the number of students attending secondary school varies greatly from country to country. One of the main factors for academic success around the world is the educational level of parents. The more educated a child's parents are, the more likely they are to get a more advanced education. Another unfortunate statistic is that while more girls attend school, both primary and secondary, they earn less than men across the board in nearly all countries surveyed. In addition, girls are much less likely to attend classes that allow them to succeed in science and math, in a ratio of almost $4: 1$ compared to boys.

There are different approaches to entering school and the age at which students can do it. Often the differences are greater in terminology than in reality, so, for example, German children can only go to school at the age of 7, but will spend several years in a school-like kindergarten, while British students go to school at the age of 4 up to 5 years old, but their first year is not too different from kindergarten classes. Preschool education in England is not compulsory, children under 5 years of age can be brought up at home $[1 ; 3]$.

In Russia, children who are six years old by September 1 of this year are admitted to the first grade of primary school. At the time of admission to the first grade, a student is usually between 6 and 8 years old [4]. 
One of the difficulties that school systems face is that if all students go to school on the same day - say early September, which is the norm in the UK - some of them will be almost a year older others, which represents a significant developmental difference. Students born in September in the UK perform more consistently in school than those born in August.

The length of study time is also an important factor, which in different countries also has its own difference.

Most school hours around the world are five or six hours long. In Brazil, this includes starting classes at 7 am and returning home for lunch; in France, classes start at 8:30 am and end at 4:30 pm, but with a two-hour lunch break in the middle of the day. British public schools usually start at 9 am and end at 3:30 pm. There may be after-school activities or homework, but formally about six hours in class is considered sufficient, especially for younger students. In Russia, classes begin at 9 am and last 5-6 hours, each lesson lasting 45 minutes, the socalled study hours, with obligatory short rest breaks lasting 15 minutes.

In contrast, South Korean high school students can sit at their desks for 14 to 16 hours. A standard school day is from 8 am to $4 \mathrm{pm}$, which is long in itself by international standards. But students in the last two grades of school will then go home for lunch, and then head back to private school between 6:00 pm and 9:00 pm for an intensive checkup. Even after all this, there may well be a couple more hours of homework. Thanks to such a rather difficult cycle of study in junior, middle and high school, South Korean students are among the most successful in international rankings, which requires a significant amount of work at all stages of education.

Philosophical approaches to teaching are clearly manifested in schools with a deep and ancient history, where national traditions still matter and are present in all spheres of society. For example, moral education is taught in Japanese schools.

Of the various approaches to education described above, the Japanese school system prioritizes the education of good citizens. Moral education has been taught informally in Japan for decades, but it is gaining importance in the Japanese curriculum as some schools teach on par with subjects such as Japanese language or mathematics.

The philosophical theme of teaching and educating with integrity and respect for elders encompasses many learning points that seem undeniable, such as compassion, perseverance, some life skills. However, it also emphasizes diligence, endurance, and generally hard work, which may seem overwhelming in other cultures, as well as topics such as national heritage, which can sometimes have a nationalist connotation when taught in a moral context, rather than being more neutral on a subject like history.

One of the manifestations of school philosophy is the school uniform of students, the attitude towards which in different countries is ambiguous.

The school uniform is a popular choice for students, parents and educators around the world. In some cases, it is widely believed that wearing uniforms makes the school population feel more united, fostering a positive sense of school spirit and community.

Often the use of school uniforms is adopted for practical reasons, since the uniform makes it easier to identify students from different schools, and in other cases, it avoids tensions due to the inequality of children from poor and rich families. There are many countries where students usually do not wear uniforms, such as the United States, France or Germany, where uniforms have nasty militaristic associations.

Where branded school clothes exist, they are carefully designed to look as unlike military uniforms as possible typically branded hoodies and T-shirts in a variety of bold colors are chosen.

Philosophy of education in various countries is considered as the most important theoretical basis for improving the pedagogical process in the field of education, creating conditions for the fullest realization of the spiritual, moral and creative potential of a person, taking into account his territorial, ethno-cultural, economic and social status [2].

Thus, having studied and analyzed modern trends in the development of education systems, and having considered the similarities and differences in teaching in different countries, we see that there is always a philosophical component in the school process, which affects in one way or another, both the organizational and technical process, and on the system of basic training of secondary school students.

Modern teachers, students of pedagogical universities in every country need to know and deeply study the philosophy of pedagogy and pedagogical methods of teaching children, not only in their own country, but also in other countries, in order to use the best achievements of the modern educational process and strive to make their own, new, since children are the common property of our World, and teachers are the first guides who show the direction to those who still have to go through this difficult life path.

\section{REFERENCES}

1. 1.Galagan A.I., Finansirovaniye obrazovaniya v razvitykh zarubezhnykh stranakh. - M.: - 2003. - S.60.

2. 2.Nikitina S.S., Pankina S.N., Filosofiya obrazovaniya: retrospektiva i metodologicheskiye podkhody. MIET // Nauchnyy zhurnal «Ekonomicheskiye i sotsial'no-gumanitarnyye issledovaniya № 1 (21). - M.: - 2019. - S. 101-112. 
3. 3.Sudorgina L. V. Obrazovatel'naya sistema sovremennoy shkoly (vzglyad iz Rossii i Velikobritanii)//Vestnik Novosibirskogo gosudarstvennogo pedagogicheskogo universiteta. № 2 (18). - N.: - 2014. - S. 7-14

4. 4.Federal'nyy zakon "Ob obrazovanii v Rossiyskoy Federatsii" N 273-FZ ot 29 dekabrya 2012 goda s izmeneniyami i dopolneniyami.

5. 5.Sheffler I. «K analiticheskoy filosofii obrazovaniya», Harvard Educational Review, № 3,- 1954. - S.- 223-230. 